\title{
The scope of public organisations with productive functions: insights from the inefficiency of Italian local public transport
}

\author{
Ugo Arrigo, University of Milano-Bicocca \\ Giacomo Di Foggia, University of Milano-Bicocca
}

\begin{abstract}
It is a well-known fact that reforms necessary to enhance competition and make the economy more attractive play a major role in the Government activity in Europe. Considering the Italian state of affairs, this paper focuses on the inefficiency of public producers in the light of certain market and legal impediments. This paper describes key barriers that undermine the healthy functioning of an important industrial and service sector of the Italian economy: specifically local public transport. This paper also sheds some light on this problem analysing the impact that a controversial regulation framework may have on an industry and suggests that the degree of liberalisation affects the return on investments.
\end{abstract}

\section{JEL classification}

H11; H40; D78.

\section{Keywords}

State-owned enterprises; efficiency; Italy; local public transport; competition. 


\section{Introduction}

The economic literature on public economics has often analysed relationships between the government, society and the market, recurrently to evaluate the role of public organisations and the impact of public policies on the functioning of modern markets. Indeed, over the past decades, there has been heightened interest in the organisation and efficiency of public organisations with vast consensus of essential key roles of modern governments that comprehend the protection of individuals' freedom, the redistribution of resources and the mitigation of market failures (Pollitt, 2004), accordingly, many scholars agree on the good reason for the existence of government organisations with productive functions. A relatively young area of research is the analysis of European integration on local governments alongside their sublevels. In this regard, it is generally acknowledged that public budgets in many European countries are under significant constraints. Schmidt (2006) argues that the institutional structure has contributed to alter the balance of power among national institutions and weakened national decision autonomy.

The efficiency of the state-owned enterprises of EU countries varies widely, however available information on their performance is fragile. Nevertheless, significant even if minute steps forward are being made in Italy, in fact, the publication of the database on SOEs (especially key accounts variables) has constituted a considerable advance over the previous situation, allowing the knowledge of the main characteristics of such firms, and facilitating the evaluation of performance according to the different industries. With this in mind, it is underlined that the performance can be strongly affected by a multitude of exogenous factors that can't be observed from our analyses. At any rate, Putnam et al. (1994) provide measures to evaluate institutional performance given that the quality of the institution is strongly correlated with growth (Arnold et al. 2011).

Prior research provides useful inputs using different approaches and shows that new challenges arise for public organisations as they have to deal with rapid and accelerating economic change, increasing complexity of regulatory issues, new technologies and services, calls for openness, transparency and citizen participation (Pitlik et al. 2012). Reforms must be implemented and sustained during times when fiscal constraints and budget consolidation pressures become increasingly tighter since good legislative frameworks can promote the healthy functioning of the market (Arnold et al. 2011).

However, regulatory frameworks (i) may be flawed by various factors that undermine their public interest aims, (ii) may involve costs that exceed their expected benefits; (iii) may suddenly become obsolete because of technical developments or the evolution of demand. Many economists tend to be inclined to foster policies aimed at increasing competition in order to increase efficiency (Amaral et al., 2009; Jonsson, 1984; Niskanen, 1973).

Such competition can also be generated with the aid of continuous productivity and efficiency comparisons between public bodies which provide similar output. Likewise, other authors have been stressing the importance of collaboration (Entwistle and Martin, 2005; Hartley et al. 2013; Osborne and Strokosch, 2013; Warner, 2011).

In this paper the ownership of enterprises is also discussed, there is in fact renewed interest in the role that SOEs can play in promoting economic development, the relationship between SOEs and the government as a shareholder, and the criteria used in assessing options for investing in or disposing of state-owned enterprises. Given the importance of a well-functioning sector and the presence of certain indications that competition in the Italian local public transport struggles (Boitani et al. 2009; IBL, 2013), we try to look at the reasons for these inefficiencies. 
In an effort to provide these concepts with more details, we focus on the performance of the selected enterprises operating in it. As the industry is strongly regulated and the behaviour of companies needs to be assessed in the context of the existing regulatory framework, we also look in broad terms at aspects of the regulatory framework. We then champion some conditions to be achieved or defended, such requirements lies in the restriction of the spoil system, choice of management made from specific lists of candidates with a certified level of expertise and based on free-access comparative selection procedures and implementation of training schools and human resources development.

Appropriate policies could provide citizens with efficient services while at the same time may contribute to the creation of an open business environment that supports the competitiveness of the industry. That said, policies will ensure that services entrusted by open, transparent and non-discriminatory tenders, make available the public service obligations and the procedures for determining compensation, and define precisely the subject of the tender and the amount of investments.

The results of our analysis suggest a positive relation between open business environment and productivity. Nevertheless this relation is only tested using the return on equity (ROE) as dependent variable consistently with the Italian Ministry of Economics. We find that SOEs operating in a highly liberalised market (energy) outperform those operating in local public transportation.

The remainder of this paper is structured as follows: in the first section, we provide a review of related literature used to introduce and support our statements. After that, the background of the Italian situation is presented; this is followed by the introduction of the Italian local public transport market. Next, the empirical analysis is performed. The discussion of the results and conclusion follow.

\section{Review of relevant literature}

The evolution of the role of government in modern states has been well documented and arguably represents one of the current most thought-provoking topics (Heady, 2001). A keystone in the classification of roles is the work of Musgrave (1959); providing for adjustments in the distribution of income and the function of contributing to stabilisation, see Habermas (1994), Dahl (1947) and Kettl (2002). Similarly, Bator (1958), Newman (1974), Brown, Potoski and Van Slyke (2006), Haque, (2001) describe the triple role of government: security of the individuals' freedom, the redistribution of resources, and the intervention in market failures. While the first two roles - redistribution of resources and the intervention in market failures - derive from the functioning of the market, as explained in normative economic theory (Buchanan, 1968; Martimort and Pouyet, 2008), the security of the individuals' freedom is a condition sine qua non of modern states (Brennan, 1977; Nozick, 1974). It might be objected thought that despite many different approaches have been proposed in an effort to shed some light on this issue the identification of scope and functions is tough (Hood, 2000). This is corroborated by Raadschelders and Lee (2011) that present a historical review of research and infer that more recent research has tended to focus on different methods, mainly regarding organisation, metrics and performance (Frederickson et al 2003; Grandy, 2009; Ostrom and Ostrom, 1971).

A critical aspect however of many studies aimed at assessing the performance of public entities in complying with their mandate is the comparability of methodology and results characterised by remarkable heterogeneity. In this sense, Afonso et al. (2005) compute public sector performance (PSP) and public sector efficiency (PSE) indicators and find differences that lead the authors to suggest paths to public savings. To the same token Dabla-Norris et al. (2012) provide a public investment efficiency index that captures the institutional environment underpinning public investment management across four different stages: project appraisal, selection, implementation, and evaluation. These studies suggest that 
governments besides the public sector play an important role in the economic life of the state through the revenue and expenditure measures. In the same fashion of the general roles outlines above the essential economic purposes orbit around are taxation and expenditure measures, stabilisation policies (required by the government to affect the levels of aggregate demand) and allocation, i.e. the provision of public goods that cannot be provided through market mechanism. In certain cases, e.g. if there is market failure, government may be able to provide the good at a more optimal level and price if compared with the market equilibrium. As a matter of fact the economic mandate justifies a productive function, eventually, in the form of public producers, both providing market and non-market goods and services.

Nonetheless, other models of provision of market and non-market goods and services exist, e.g. public-private partnerships are growing in popularity as a governing model (Forrer et al., 2010). As a producer of goods and services, public administration plays a significant role for the well-being of citizens and the competitiveness of countries.

Hence, the questions of which factors improve performance and raise capacities of a public administration to provide goods and services efficiently are at the heart of all discussions about public sector reforms (Pitlik et al., 2012). To this regard a great deal has been written about the politics-related factors that impact on performance of firms (Al-Obaidan and Scully, 1992; Bottasso and Sembenelli, 2004; Sapienza, 2004; Shleifer and Vishny, 1994; Zheng et al. 2003). Amaral (2008) analyses the determinants of the performance differential between the private and public management of urban public transport in Europe. According to the author, private management is associated with lower operating costs; however, the differential can depend on the interaction of the local authorities' capacity for expertise and the private operators' autonomy margin. In terms of total costs, no systematic advantages should be expected from private management. Despite significant regional variation both between and within different regions, there is widespread consensus on the scope of SOEs, for example, to correct market failures, provide public goods, and foster economic development (Kowalski, Büge, Sztajerowska and Egeland 2013). The previously mentioned productive functions justify certain public producers (Arrigo and Di Foggia, 2013; Dewenter and Malatesta, 2001; Toninelli, 2000).

Although the government as a regulator and owner of assets opens a possibility of favourable treatment granted to SOEs (Kowalski, Büge, Sztajerowska and Egeland, 2013), it may be argued that there is, however, still little reliable information on their efficiency and on the advantages they may be enjoying because of their ownership since SOEs increasingly compete with private firms.

Firms frequently interact with public administration in many different ways and in a variety of different circumstances. In addition, firms indirectly rely on public administration outputs. Thus, an efficient public administration that efficiently provides public goods and services and that absorbs relatively few public resources affects productivity and competitiveness of firms (Afonso et al. 2005; Allum, 1974; Calandra, 1978; Fratianni and Spinelli,1982; Ongaro, 2004; Torres, 2004). Other authors provide pieces of evidence on the causes of inefficiency (Capano, 2003; Cassese, 1993; Del Monte and Papagni, 2001; Tanzi, 1998). Bandiera et al. (2008) estimate the cost of active (its presence entails direct or indirect benefit for the public decision-maker) and passive (its presence does not advantage the public decision-maker) waste from observed costs of public services.

The authors assess the impact on how efficiently a certain public service is provided. Their model focused on generic goods purchase which account for 40 per cent of public spending for goods and services. Their findings suggest that the difference in prices across public bodies is principally due to variation in passive 
(83 per cent of total) rather than active waste. Based on average total cost (Frank, Bernanke and Johnston, 2007) show that productive inefficiency implies an excess of production costs. Other noteworthy and widely investigate elements that concur to determine the average low performance of Italy are both clientelism (Caciagli, 2006; Della Porta and Vannucci, 1997; García, 2013; Guzzini, 1995) and corruption. Also results of a recent study (Fiorino et al. 2012) confirm evidence of a negative correlation between corruption and growth.

At the time of writing a controversial topic is the underperformance of local public transport or LPT sector. It is generally acknowledged that public budgets, including those dedicated to cover public transport, are under significant constraints. Recent austerity measures have affected this sector too. Between 2010 and 2012, the industry witnessed an overall decline in resources (600 million) or -12 per cent of public contributions. The reduction of public transfers has triggered a general tendency to raise the price of tickets. According to a recent fact-finding investigation of the Italian Competition Authority (AGCOM, 2014), the ongoing situation of general inefficiency and lack of financial resources is largely attributable to the ownership, the management objectives and the regulatory framework that is layered and not always consistent. As highlighted by Asquer (2011), local public transport has traditionally been operated by local state-owned enterprises - SOEs. Boitani et al. (2009) investigate how the ownership and the procedure for the selection of firms operating in the local public transport sector affect their productivity. In order to compare different institutional regimes, they carry out a comparative analysis of companies operating in large European cities. The authors find that when firms are totally or partially in public hands their productivity is lower.

Moreover, firms selected through competitive tendering display higher total factor productivity. However there are cases of SOEs success worldwide and some SOEs are closing the gap with their private-sector competitors.

As far as we know, there are, however, few studies that specifically analyse SOEs based on profitability measures. Bovaird and Löffler (2009) provide some highlights on key concepts of management and performance measurement that include profitability ratios. In fact the profit made by organizations can be effectively evaluated when compared to the amount of resources and activity required to generate it. Return on investment (ROI) is a widely used measure of overall performance and there are two key approaches to ROI (Walsh, 2003). The first approach is based on the Return on Total Assets (ROTA) or Return on Capital Employed (ROCE) which focuses on operating efficiency of the total enterprise.

The second approach, employed in this paper, is based on the Return on Equity (ROE), which concentrates on performance efficiency as translated into return to shareholders. It is anticipated that this approach opens to several interpretations.

\section{Background}

\subsection{Unsuitability of regulation prevents the healthy functioning of local markets}

A breakthrough in regulatory policy during the last decades has been the awareness that government objectives for the utility industries can also take benefit from facilitating competition (Arrigo and Di Foggia, 2013). The European Commission enforces competition rules towards a single market by ensuring that all companies compete equally and fairly (European Commission, 2014a). This benefits consumers, businesses and the economy as a whole.

The competitive market is primarily a selection mechanism of economic behaviour, evaluated in terms of efficiency, able to protect consumers and ultimately the general public from the effects of poor decisions made by producers. 
Still, if competition does not seem possible with regards to public organisations that produce administrative acts, it may be introduced for SOEs that compete with private companies under specific rules and in viable sectors. This can introduce adequate competition for services that will be offered by many organizations using the same infrastructure, as it is not economically convenient to duplicate it (OECD, 2004). To this extent, Arnold et al. (2011) underscore that regulation generally addresses public-interest concerns about market failures, including monopoly conditions, externalities and asymmetric information. In this context, a good regulation can promote competition in certain industries by ensuring that market power in natural-monopoly segments is not used abusively and by providing the correct incentives to business participants.

However, regulatory frameworks may be flawed by various factors, thus (i) some regulations may drift away from their original public interest aims, (ii) regulations sometimes involve costs that exceed their expected benefits and (iii) technical development, the evolution of demand and progress in regulatory techniques can make the design of regulations obsolete.

Even if it does not create effective competition, the separation of production and distribution would make the introduction of forms of comparative competition between suppliers operating in different geographical areas possible. The same method may also be introduced in order to evaluate the performance of similar offices in the typically public area of the production of administrative acts.

\subsection{Degree of liberalisation}

The World Economic Forum defines competitiveness as the set of institutions, policies, and factors that determine the level of productivity of a country. At the roots of competitiveness are the institutional and microeconomic policy arrangements that create the right conditions for a wealthy business environment under which businesses can grow (European Commission, 2014b). By analysing eight sectors, Asquer (2011) suggests that the difficulty to implement liberalisation and regulatory reforms in Italy may be explained by various concurrent forces, which have to do with: the rent-seeking behaviour, the rise of barriers to entry against competitors, and the risk of collusive practices between regulators and regulated. It becomes therefore important to shed some light on factors that impact the efficiency of Italian public administration. Table 1 gives an idea about the rank of liberalisation in different sectors in Italy. For each sector a number of criteria are employed in order to assess the existence of barriers to entry in, organization within, and exit from the market. The existence of such barriers is inferred from a number of quantitative as well as qualitative indicators. Among the former, concentration indices, price dynamics, the public vs. private ownership of the incumbents, and other structural indicators are considered. Among the latter, the Index of Liberalisation looks at such indicators as the degree of unbundling for essential facilities in network industries, the existence of fiscal or legal discriminations against the newcomers, the regulatory quality, etc. 
Table 1: Index of Liberalisation (Italy)

\begin{tabular}{|c|c|c|c|c|c|c|c|}
\hline Sectors & 2007 & 2008 & 2009 & 2010 & 2011 & 2012 & $2012 / 07^{*}$ \\
\hline Natural Gas & 48 & 54 & 52 & 55 & 62 & 64 & +16 \\
\hline Post & 37 & 38 & 38 & 41 & 47 & 52 & +15 \\
\hline Electricity & 63 & 65 & 69 & 71 & 72 & 77 & +14 \\
\hline Labour Market & 50 & 35 & 55 & 60 & 60 & 60 & +10 \\
\hline Motorway & 32 & 32 & 29 & 29 & 28 & 40 & +8 \\
\hline Financial Services & 59 & 62 & 63 & 64 & 69 & 66 & +7 \\
\hline $\begin{array}{l}\text { Professional } \\
\text { orders }\end{array}$ & 46 & 46 & 47 & 47 & 47 & 52 & +6 \\
\hline Italy (total) & 47 & 47 & 49 & 48 & 49 & 52 & +5 \\
\hline $\begin{array}{l}\text { Telecommunicatio } \\
n\end{array}$ & 40 & 35 & 39 & 41 & 42 & 45 & +5 \\
\hline Art & 55 & 55 & 56 & 56 & 56 & 58 & +3 \\
\hline Inland revenue & 44 & 43 & 52 & 48 & 48 & 47 & +3 \\
\hline $\begin{array}{c}\text { Public } \\
\text { administration }\end{array}$ & 40 & 37 & 35 & 38 & 39 & 42 & +2 \\
\hline $\begin{array}{l}\text { Local public } \\
\text { transport }\end{array}$ & 45 & 46 & 43 & 43 & 44 & 45 & 0 \\
\hline Airways & 66 & 70 & 68 & 60 & 62 & 65 & -1 \\
\hline Water & 27 & 27 & 32 & 17 & 19 & 19 & -8 \\
\hline TV & 70 & 68 & 67 & 65 & 62 & 61 & -9 \\
\hline Railways & 49 & 49 & 49 & 41 & 36 & 36 & -13 \\
\hline
\end{tabular}

Table 1 also shows the overall rankings of the IBL liberalisation index, comparing this year's rankings with those from the previous edition of the index, showing all sectors ranked together. As Graph 1 shows the IBL Index of Liberalisation appears to be correlated with the World Economic Forum's Competitiveness Index while it is negatively correlated with the OECD State Control indicator (The indicator covers formal regulations in the area of state control of business enterprises). These relationships support the idea that the selected index captures factors that are important for developing the LPT industry. On the same basis we see the IBL Liberalisation Index is taken as a reference for measuring the liberalisation degree of two Italian sectors, namely LPT and energy to be used in our analysis. 
Graph 1: Correlation between IBL's Index of Liberalisations, WEF's Competitiveness index and OECD State Control Indicator

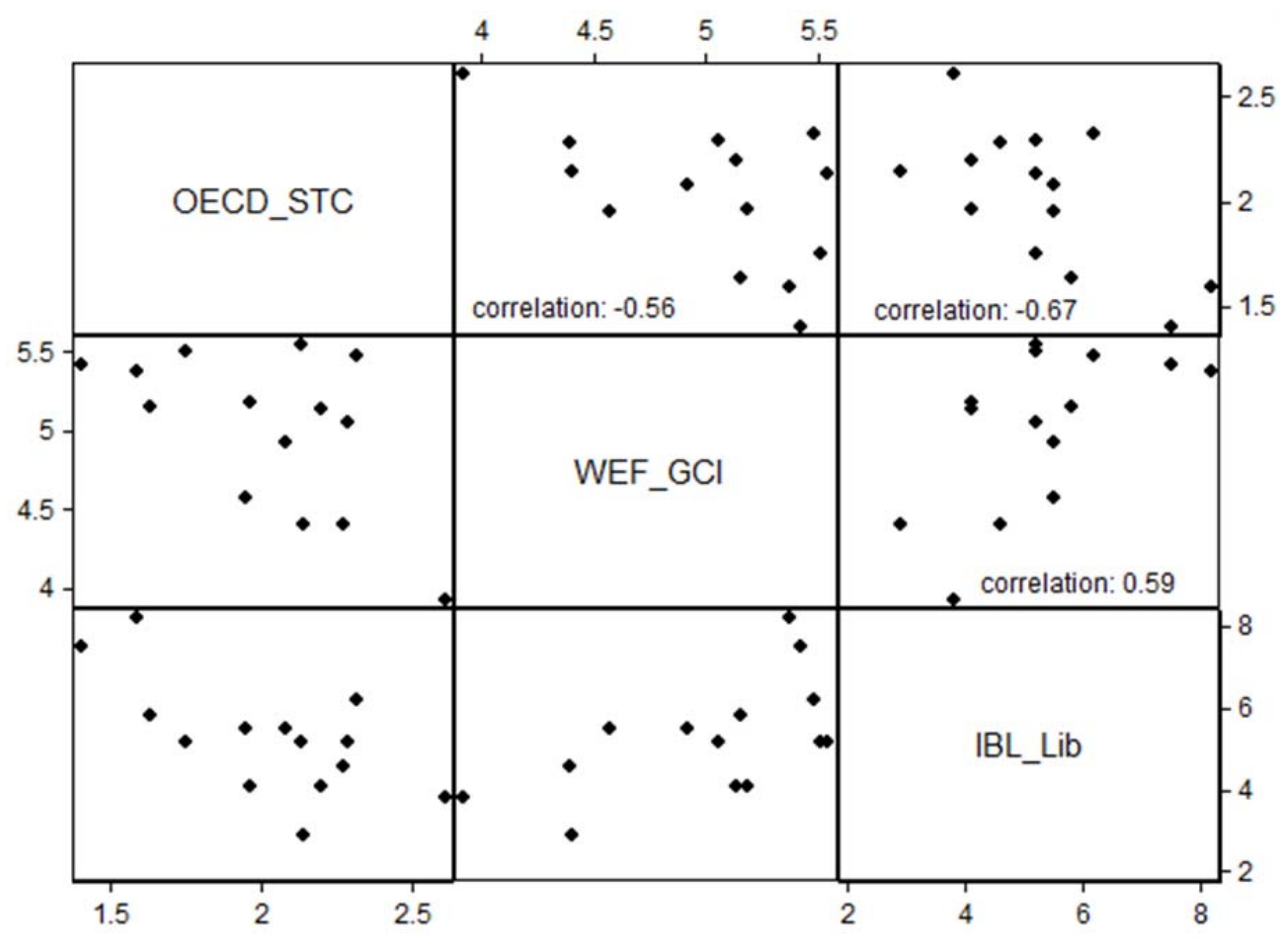

Source: own elaboration based on IBL liberalisation index (IBL_Lib), OECS State Control indicator (OECD_STC), WEF competitiveness index (WEF; GCI). Reference year: 2013.

\subsection{The ownership of organisations}

There are well-known differences between governance of public and private companies (Rainey et al. 1976) and the concept of governance is a growing body of European literature (Peters and Pierre, 1998). Although state-owned enterprises as government assets open a possibility of favourable treatment these organisations may cope with multiple, unclear, or conflicting financial and social objectives. Political interference can prompt decisions that threaten a company's financial goals; therefore, managers can find it thorny to match the private sector's performance standards. The defining characteristics of such organisations are that they have a distinct legal form and they are established to operate in markets even in they may also have public policy objectives.

To better comprehend the struggle of public management and decision-taking process one must remember that administrative action within the sphere of the state that produces administrative acts, is governed by rigid written procedures that are consistent with the justice/equality objectives that administrative action pursues. Garrone et al. (2013), underline that management discretion is a significant source of inefficiency in municipal enterprises. Public sector organisations are similar to private companies since they have hierarchical structures that impose mandatory allocations of productive factors.

However, while in private companies personal authority as defined by Arrow (1974) is dominant, in public organisations impersonal authority prevails, consisting of written rules and laws and regulations that are relatively rigid and stable over time (Arrow, 1974). In this way, public sector organisations do not benefit from the advantage that private companies have, represented by non-rigidity and the open and only partially predetermined content of work contracts. In private companies, the rules and procedures are subject to the leadership, on the contrary, in public organisations, leadership is subject to rules. Therefore, in the case of poor legal 
systems, when producing services for citizens, managers slog to achieve dynamically efficient solutions. Dwyer and Edwards (2009) digest this concept: dealing with change in the external environment creates considerable challenges for managers. Given the complexity of strategy formulation it is difficult for managers to analyse all aspects of their environment or establish precise objectives, consequently business strategies tend to be characterised by small strategic adjustments or "incrementalism".

However, these marginal adjustments of strategy within an organisation's existing culture may lead to strategic drift reflecting strategies that are inconsistent with changes taking place in the external environment. Besides, Andrews et al. (2006) show that the organisational failure is to some extent attributable to difficult circumstances and management features such as weak leadership and poor performance management.

Ongaro and Valotti (2008) identify some factors affecting implementation of public management reform: characteristics of the administrative tradition and features of the politico-administrative context; the design of the reform package and the coalition of interests sustaining the reform; behavioural triggers; and the building over the time of management capacity at the level of individual public sector organisations.

According to the financial police, in 2013 , fraud and waste amounted to $€ 5$ billion and (over 19,000 managers identified by the military). Specifically, the complaints to the judicial authorities, concerning crimes against the public administration, were more than 4,300 among others: bribery, extortion, embezzlement, misappropriation of funds, and abuse of office. The offences were put in place by directors, officers and civil servants alike. Additionally, it is worth noting that, results of 25,000 inspections performed in 2013 show that among 1,704 public employees (total public employees amounted to 3.3 million) were sued for incompatibility with other assignments or jobs (GdF, 2013).

State-owned enterprises may be overmanned to please employees that are voters too (Boycko et al. 1996). Non-commercial purposes can also make a firm vulnerable in the wage-bargaining process (Haskel and Szymanski, 1992). Willner (2001) presents conditions under which political interference yields higher welfare than under commercial purposes, and vice versa. This supports a further efficiency gap of public organisations linked to the control of the organisation by politicians, resulting in resources for institutional duties instead being used by the political class, above all to bestow private benefits to constituencies (Boubakri et al. 2008).

The data presented in Table 2 relate to 6,151 companies out of a total of 7,065 participated. In particular, for about 700 companies no data were available and so they were excluded. Nevertheless, according to Spicer (2010), scholars have too often been condescending towards the linkages between politics and governance, viewing political activities and interests as opportunities for corruption, mismanagement, and skewed priorities.

Table 2: participated companies (by local administrations)

\begin{tabular}{|c|c|c|c|c|}
\hline Performance & $\begin{array}{l}\text { Number of } \\
\text { companies }\end{array}$ & Percentage & $\begin{array}{l}\text { Operative result } \\
\text { (billion } €)\end{array}$ & $\begin{array}{c}\text { Average share } \\
\text { (participation) }\end{array}$ \\
\hline Profit & 2879 & $47 \%$ & 1.413 & $29 \%$ \\
\hline Neutral $^{*}$ & 1249 & $20 \%$ & & $60 \%$ \\
\hline Loss & 2023 & $33 \%$ & -2.214 & $15 \%$ \\
\hline Total & 6151 & $100 \%$ & -0.801 & \\
\hline
\end{tabular}

\subsection{The LPT industry}

At the time of writing a controversial issue is the apparent underperformance of local public transport sector. According to a recent fact-finding investigation of the 
Italian Competition Authority (AGCOM, 2014), the ongoing situation of general inefficiency and lack of financial resources is largely attributable to the ownership and the management objectives. The report highlights several critical issues, among others: the organisation and procedures to select service operators (in many cases, the transport services are entrusted to state-owned inefficient companies or are managed on the basis of repeated extensions); the lack of transparency, efficiency and regulation of contracts, the overlap of activities of entrusted operators: monopoly and competition and problems that arise with respect to the determination of compensation, often awarded on the basis of criteria not aimed at efficient costs. The inefficiency of SOEs can generate losses other than the operating ones ( $€ 1.2$ billion in 2012 according to the Italian Competition Authority). Even if almost all industries in which SOEs operate underperform, remarkable losses refer to the LPT ( $€ 300$ million in 2012), other nonoperating losses are funded indeed by service contracts and government transfers (to current or capital account), or by citizens through tariffs based on the service total cost, e.g. the waste management sector.

As highlighted by Asquer (2011), local public transport has traditionally been operated by local SOEs. In addition, the regulatory framework is layered and not always consistent. As per the market structure one may note that the LPT sector is highly regulated, and differently from other European countries, on the supply side, there are plenty of SMEs. A European comparison shows that in Italy the market share of the top three operators is equal to 26 per cent compared to 56 per cent in the UK, 77 per cent in France and 40 per cent in Sweden, and that 88 per cent of enterprises have fewer than 100 employees. Other data are shown in Table 3.

Amaral (2008) analyses the determinants of the performance differential between the private and public managements of urban public transport in Europe. According to the author, private management is associated with lower operating costs; however, the differential can depend on the interaction of the local authorities' capacity for expertise and the private operators' autonomy margin. In terms of total costs, no systematic advantages should be expected from private management. Boitani et al. (2009) investigate how the ownership and the procedure for the selection of firms operating in the local public transport sector affect their productivity. In order to compare different institutional regimes, they carry out a comparative analysis of companies operating in large European cities. The authors find that when firms are totally or partially in public hands their productivity is lower. Moreover, firms selected through competitive tendering display higher total factor productivity. However, there are cases of SOE success worldwide and some SOEs are closing the gap with their private-sector competitors.

Table 3: key data of the LPT Industry

\begin{tabular}{ccc}
\hline TPL industry & Values $(\approx)$ & Unit of measure \\
\hline Companies & 1150 & Number \\
Employees & 116500 & Number \\
Turnover & 10 & Billion $€$ \\
Kilometres year (billion) & 5.4 & Billion Km \\
Fleet $\left(\mathrm{N}^{\circ}\right)$ & 50000 & Number \\
Buses & 92 & Share $(\%)$ \\
Other means & 8 & Share $(\%)$ \\
\hline
\end{tabular}

It is worth noting that 82 per cent of the production value comes from SOEs, which run 95 per cent of the urban transport services and 75 per cent of suburban public transport services. In 2013, most of the companies generated losses, with worse outcomes compared to those of other European countries (UK, Germany, France, Sweden, the Netherlands and Belgium). In the segment of road transport, the average EBIT (-1.1 per cent) is poorer than the European average (3.5 per cent). The comparison with other countries is also negative considering the revenue per $\mathrm{km}$ of traffic $(€ 1.08$ against a European average of $€ 1.34)$ and the public contributions $€ 2.2 / \mathrm{Km}$ against a $€ 1.4 / \mathrm{Km}$ European average of (AGCOM, 2014). 
Table 1 shows that while the Italian situation increased from 2007 to 2012, local public transport did not. It is important to emphasise the referendum held in 2011 that has affected the existing rules of local public services and in particular on local public transport (DPR, 2011). The mentioned referendum has limited the floor for fair competition in the field of local public transport. Furthermore, the structure of the Italian LPT industry is characterised by fragmentation as several firms operate in relatively small user basin areas. Asquer (2011) advises that, considering the Italian environment, LPT has been traditionally run by local state-owned enterprises.

Graph 2: IBL Liberalisation Index - focus on Energy and LPT

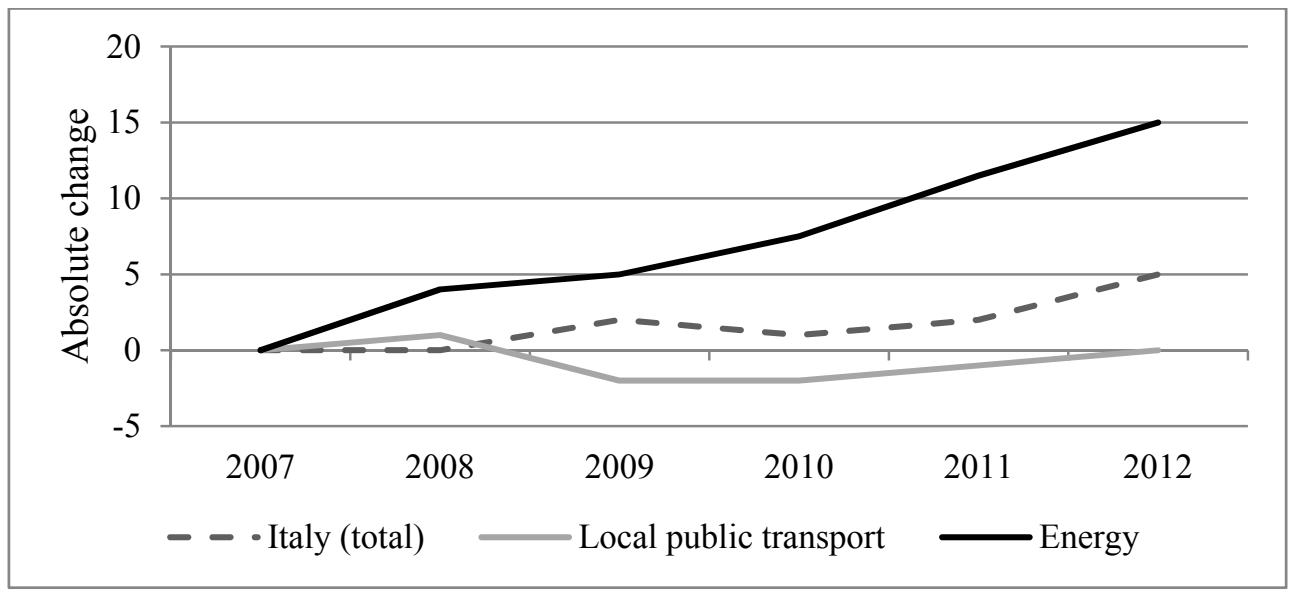

Source: own elaboration on IBL (2012). Energy = Electricity + Gas

\section{Empirical analysis}

Our primary source of data is the database of companies wholly or partially owned by the government (at different levels) published in 2014 by the Ministry of Economy and Finance (MEF). This choice was aimed at getting a general picture of the performance of the firms listed in the database. For our analysis, we managed to retrieve additional financial information and contextual variables from reliable sources: ISTAT as per contextual variables and Amadeus, a database of comparable financial information for public and private companies. We decided to omit variables related to industrial output and to take into consideration industrial activities and location to group the information. The statistical technique employed was OLS regression. One of the principal challenges inherent in this approach besides the assumption that the data are independent - was the lack of a definitive and universally accepted variable to be used as an object for the evaluation or dependent variable; thus we decided to employ the same index of the MEF report; the return on equity - ROE. Serious precautions were taken accurately and thoroughly to screen, clean and model the data in an effort to enhance results: 1,554 firms out of 3,500 used. The main limitation of the variables omission is the amount of variance accounted for in the response variable by the predictors. Rsquared in fact indicates that the model accounts for a very low variance. However, provided the purpose of this paper, major benefits of models predominate. Our work clearly has some limitations: sample, methodology, and absence of a time element to foster causal relations.

\subsection{Variables}

The key variable for the performance appraisal of the firms is ROE, which is the most valuable indicator. It includes both dividends paid to shareholders and the retained profit which technically belongs to shareholders and which generates future capital growth (Pizam, 2010). Since the ROE is useful for comparing the 
profitability of a company to that of other firms in the same industry, we add some dummy variables to define both industrial activities and geographical distributions. As follows, the used variables accompanied the meaning.

- ROE: return on equity (retrieved for 2011, 2012 and 2013)

- EP: (operating revenue/cost of employees) ${ }^{*} 100$

- EMPL: log of employees 2012

- PRCO12: log of Total production cost

- PRVA12: log of total production value

- DERD: debt equity ratio 2012 - debt equity ratio 2011

- AV12: added value per capita

- CL12: cost per employee

- GDP12: gross domestic product at NUTS3 level (Italian provinces)

- POP: population of the municipality

- ALT: log of altitude (metres)

- NET: dummy variable, it takes a value of 1 for companies that operate in a typical network public service (energy, gas, water, LPT, waste) 0 otherwise.

- ENERGY: dummy variable, it takes a value of 1 for companies that operate in the energy sector "energy", 0 otherwise

- TPL: dummy variable, it takes a value of 1 for companies that operate in the LPT sector, 0 otherwise.

- NCS: $1=$ North, 2=Centre, 3=South and Islands (Sicily and Sardinia).

\subsection{Evidence}

Table 4 presents correlations (2012 and 2013) for return of equity and financial output per employee, PE. Weak even if interesting features emerge from a reading of this table. Profitability of the analysed companies slightly decreases in southern regions, Sicily and Sardinia.

Table 4: Correlation of some variable with geography

\begin{tabular}{cccccc}
\hline Variables & ROE13 & ROE12 & EP13 & EP12 & NCS \\
\hline ROE13 & 1 & & & & \\
ROE12 & 0.44 & 1 & & & \\
EP13 & 0.13 & 0.10 & 1 & 1 & 1 \\
EP12 & 0.12 & 0.14 & 0.88 & -0.06 & Source: own elaboration. \\
NCS & -0.02 & -0.06 & -0.08 & &
\end{tabular}

Similarly, correlations for independent variables used in the models are shown in Table 5. Unsurprisingly PRCO12 and PRVA12 are highly correlated, however this feature does not undermine the effectiveness. All other variables are pretty much uncorrelated. 
Table 5: Correlation of dependent variables

\begin{tabular}{|c|c|c|c|c|c|c|c|c|c|}
\hline & & PRCO1 & & & & & & & \\
\hline & EMPL & 2 & PRVA12 & DERD & AV12 & CL12 & GDP12 & POP & ALT \\
\hline EMPL & 1 & & & & & & & & \\
\hline PRCO12 & 0.86 & 1 & & & & & & & \\
\hline PRVA12 & 0.85 & 1.00 & 1 & & & & & & \\
\hline DERD & -0.07 & -0.02 & -0.02 & 1 & & & & & \\
\hline AV12 & 0.03 & 0.37 & 0.40 & -0.02 & 1 & & & & \\
\hline CL12 & 0.25 & 0.43 & 0.43 & -0.01 & 0.54 & 1 & & & \\
\hline GDP12 & -0.04 & 0.03 & 0.04 & 0.05 & 0.13 & 0.03 & 1 & & \\
\hline POP & 0.26 & 0.27 & 0.27 & -0.01 & 0.08 & 0.18 & 0.00 & 1 & \\
\hline ALT & -0.15 & -0.15 & -0.16 & -0.01 & -0.05 & -0.10 & 0.12 & -0.46 & 1 \\
\hline
\end{tabular}

Our first estimation results are shown in Table 6, which presents several alternative specifications of our reference model in column (1) that represents the starting point. In model (2) the variable NET identifies the network public services, within model (3) the energy \& gas sector is defined by the variable ENERGY, while the model (4) is aimed at characterise the LPT sector. The model in column (1) provides broad preliminary support for our further assumptions regarding the determinants of ROE. First, with respect to production cost PRCO12 and value PRCO12, we find that coefficients are as expected negative in the case of PRCO12 and positive considering PROVA12, both at the 1 per cent significance level. In line with what anticipated we find a negative coefficient associated with the number of employees EMPL, also $(p<0.001)$. Moreover, the gross domestic product per capita has a positive impact on the return of equity $(p<0.001)$. A morphological characteristic, the altitude ALT, though $(p<0.1)$ negatively influences the performance too. It must be stressed that factors that do not show up as significant are by no means unimportant. 
Table 6: Model outputs

\begin{tabular}{|c|c|c|c|c|}
\hline VARIABLES & $\begin{array}{c}(1) \\
\text { ROE }\end{array}$ & $\begin{array}{c}(2) \\
\text { ROE }\end{array}$ & $\begin{array}{c}(3) \\
\text { ROE }\end{array}$ & $\begin{array}{c}(4) \\
\text { ROE }\end{array}$ \\
\hline EMPL & $\begin{array}{c}-2.876^{\star \star *} \\
(0.788)\end{array}$ & $\begin{array}{c}-2.933^{\star \star *} \\
(0.789)\end{array}$ & $\begin{array}{c}-2.537^{\star \star *} \\
(0.800)\end{array}$ & $\begin{array}{c}-2.558^{\star \star *} \\
(0.795)\end{array}$ \\
\hline PRC012 & $\begin{array}{c}-54.01^{* * *} \\
(4.460)\end{array}$ & $\begin{array}{c}-54.11^{* * *} \\
(4.462)\end{array}$ & $\begin{array}{c}-54.29^{* * *} \\
(4.457)\end{array}$ & $\begin{array}{c}-53.23^{\star * *} \\
(4.461)\end{array}$ \\
\hline PRVA12 & $\begin{array}{c}57.06^{* * *} \\
(4.746)\end{array}$ & $\begin{array}{c}57.06^{* * *} \\
(4.747)\end{array}$ & $\begin{array}{c}56.92^{* * *} \\
(4.741)\end{array}$ & $\begin{array}{c}56.11^{* \star *} \\
(4.750)\end{array}$ \\
\hline DERD & $\begin{array}{c}-0.00244^{\star \star *} \\
(0.000709)\end{array}$ & $\begin{array}{c}-0.00245^{\star * *} \\
(0.000709)\end{array}$ & $\begin{array}{c}-0.00250^{* * *} \\
(0.000708)\end{array}$ & $\begin{array}{c}-0.00241^{\text {*** }} \\
(0.000708)\end{array}$ \\
\hline AV & $\begin{array}{l}-1.940 \\
(1.308)\end{array}$ & & & \\
\hline CL12 & $\begin{array}{c}0.136 \\
(1.304)\end{array}$ & & & \\
\hline GDP12 & $\begin{array}{c}6.351^{* * *} \\
(2.202)\end{array}$ & $\begin{array}{c}6.578^{* * *} \\
(2.212)\end{array}$ & $\begin{array}{c}6.425^{\star * *} \\
(2.202)\end{array}$ & $\begin{array}{c}6.103^{* * *} \\
(2.202)\end{array}$ \\
\hline POP & $\begin{array}{c}-0.113 \\
(0.338)\end{array}$ & & & \\
\hline ALT & $\begin{array}{l}-0.659^{*} \\
(0.340)\end{array}$ & $\begin{array}{c}-0.687^{\star *} \\
(0.340)\end{array}$ & $\begin{array}{c}-0.718^{\star *} \\
(0.340)\end{array}$ & $\begin{array}{l}-0.613^{*} \\
(0.339)\end{array}$ \\
\hline NET & & $\begin{array}{c}1.421 \\
(1.223)\end{array}$ & & \\
\hline ENERGY & & & $\begin{array}{l}4.794^{* *} \\
(2.056)\end{array}$ & \\
\hline TPL & & & & $\begin{array}{c}-6.390^{* * *} \\
(2.328)\end{array}$ \\
\hline Constant & $\begin{array}{c}-68.84^{* \star *} \\
(22.51)\end{array}$ & $\begin{array}{c}-70.55^{\star \star *} \\
(22.57)\end{array}$ & $\begin{array}{c}-67.41^{\star \star \star} \\
(22.51)\end{array}$ & $\begin{array}{c}-66.18^{* \star *} \\
(22.51)\end{array}$ \\
\hline Observations & 1,554 & 1,553 & 1,553 & 1,553 \\
\hline R-squared & 0.152 & 0.153 & 0.155 & 0.156 \\
\hline
\end{tabular}

The results in model alternatives in Table 6 are generally consistent with those in the model (1) and in particular reinforce our arguments. All of the variables that were significant in column (1) remain significant. Overall, the results of the three regression analyses, columns (1), (2) and (3) with ROE as dependent variable reveal a number of insights into what how the industrial activity (NET stands for network public service, LPT because of its low liberalisation rank and ENERGY since one of the most liberalised sectors) contribute to the measure of performance. Considering the model in column (2) one may note the coefficient is positive though not significant. Indeed, coefficients associated with the dummy variables ENERGY, positive $(p<0.05)$, and LPT, negative $(p<0.01)$ are both significant.

\section{Discussion and conclusion}

Examining our results, we speculate that while not all of the results were significant, the overall direction of results showed trends that could be helpful to learning about profitability of local public transport. Indices that measure the efficiency of the participated companies can be an important stimulus to their performance improvement. The database published by the Ministry of Economics and Finance reports a well-known index of efficiency, namely the return on equity ROE. Return on Equity measures a corporation's profitability by revealing how much profit a company generates with the money shareholders have invested. Noticeably profitability measures alone fail to capture in full the performance of SOEs because of the scope that these organisations pursue. In addition, although state-owned enterprises as government assets open a possibility of favourable treatment, managers of these organisations may cope with multiple, unclear, or conflicting financial and social objectives, therefore, they can find it thorny to match the private sector's performance standards. As anticipated in the literature section 
there are contrasting studies focused on the eventual political interference and on its effective ability to prompt decisions that threaten a company's financial goals.

Our findings share a number of similarities with those reported in some of the papers above mentioned and in terms of the models presented in Table 6, results support the theoretical assumption that different levels of liberalisation associated with different industrial activities affect the ROE. Apparently, a competitive environment with a sound regulatory framework may enable improvements in the profitability of firms, specifically the performance efficiency as translated into return to shareholders. In addition coefficients associated with the dummy variables ENERGY, positive $(p<0.05)$, and LPT, negative $(p<0.01)$ are both significant, therefore as put forward, our results show different profitability of firms across different markets, regulatory frameworks and competition levels. Given that our findings are based on a limited number of firms, the results from such analyses should consequently be treated with the utmost caution. Important limitations might have influenced the results obtained, allowing alternative explanations. In particular, as previously indicated, it is possible that inefficiency may be driven more by omitted forces than by the variables highlighted in our theoretical and empirical arguments.

As per the regulation of local public services, the current situation is at a standstill. Although the goal is to move from a system of attribution of exclusive rights by issuing administrative orders to the liberalisation of the service, which entails the consequent free delivery, some critical aspects must be considered, among others the public service obligations to be observed by the operating entity, the definition of economic compensation and the issue of minimum standards (efficiency and quality) of services to be provided. We underline the need for high quality services granted in efficient and affordable procedures and providing all stakeholders with the required legal certainty. In this sense appropriate policies would provide people with efficient services while at the same time contribute to the creation of an open business environment that supports the competitiveness of the industry. As a premise, the simplification of the market access procedure, in terms of time required for authorisation is needed. At the same time the widely recognised lack of transparency in the current system impedes the efficient development of this market. We claim that the completion of the liberalisation and simultaneously the privatisation of a number of enterprises would pilot a better allocation of resources and consequently to an increase of the demand (apparently under the level of the mentioned European countries). As a matter of fact, according to OECD (2006), SOEs face explicit difficulties regarding their governance since are often effectively protected from two major threats i.e. threat of takeover and bankruptcy. Data in Table 7 seem to confirm that problems arise when control of public entities exceed the 50 per cent. We also agree with findings of the Competition authority AGCOM (2014) who advises that the most important aspects for the market development are the proper definition of the areas of public service, both in terms of territory as regards the nature of the services offered and the definition of minimum services and the related question of the correct quantification of the compensation of the public service obligations.

Table 7: Net Income per employee and EBITDA margin (Italy - EU 15)

\begin{tabular}{cccc}
\hline \multirow{2}{*}{ country } & Public ownership & EBITDA & $\begin{array}{c}\text { Net Income per } \\
\text { Employee }\end{array}$ \\
\hline \multirow{2}{*}{ IT } & $>50.01 \%$ & 8.05 & -2.69 \\
& $\leq 50 \%$ & 10.11 & 43.80 \\
EU-15 & $>50.01 \%$ & 11.18 & 18.39 \\
& $\leq 50 \%$ & 13.24 & 74.39 \\
\hline
\end{tabular}

Our results contribute to the literature on the governance of Italian public transport by focusing on how different market structures influence the profitability of firms. Results support leaders of public sector organisations as well as policy makers. 
Our research suggests that, as per the profitability of firms within the LPT sector, SOEs could boost their productivity. However, companies and other organisations and policy makers need to address considerable challenges if they are to capture the full potential of such markets.

\subsection{Conclusion}

In this paper, we have highlighted that public organisations with productive responsibilities - public producers - may face multiple problems linked to the ownership, the management, the regulatory framework and the degree of competition of the markets in which they operate. This is done in conformity with the findings of the European Commission (2014b) report on competition as it shows that competition enforcement helps promoting growth and competitiveness of states, prevents dominant companies from expelling competitors from the market, keeps markets open and efficient, and creates the conditions for lower input prices for the industry. As per the government expenditure related to SOEs (also in the form of state aid), policies aimed at enforcing competition help to steer public resources towards growth-enhancing objectives. Indeed, on the one hand we have stressed that like unlawful government subsidies, unproductive government expenditure in SOEs can distort the level playing field, erect superfluous barriers and undermine the growth potential. On the other hand, we have also pointed out that government support and intervention can also have a positive impact when it is well-targeted.

We advocate that efficiency and profitability problems arise in markets characterised by biases in some of the above mentioned aspects which threaten competition. This is particularly true in those markets where governments tend to intervene to protect incumbents. Focusing on local public transport, we have highlighted critical aspects that have a negative impact on market development. Specifically, the evidence of this study and the related literature points towards the idea that both exogenous factors like the regulatory framework and the level of competition coexist with endogenous factors (ownership and size) and mutually concur to the inefficiency of LPT. Given these points, we have underlined that the results of our estimates reinforce our arguments. Our results endow preliminary support for our assumptions. Overall, the results of the three regression analyses reveal a number of signals on how the market structure impacts on the employed measure of performance, the ROE. Indeed, coefficients associated with the variables aimed at identifying the energy and LPT markets, confirm the better performance of firms operating in the energy market. The findings are not representative of the entire SOEs universe firstly because of the lack of consistent and robust information and secondly because in line with the opening decision this paper does not address in detail the potential additional affecting forces. The results however will be trusted considering the uniformity with most of the dedicated literature, though the findings cannot be generalised to other markets, countries or even measures of performance.

Our research suggests that policies aimed at containing government expenditure and in the meantime increasing the efficiency of the services provided will (i) ensure that service operators are entrusted by open, transparent and nondiscriminatory tenders and procedures, (ii) put at the disposal of all potential operators clear and sound rules to comply with the public service obligations and simplify procedures for determining compensation, and (iii) define precisely the subject of the tenders in order not to hamper considerably the participation of new entrants.

The findings of this research have managerial implications too. Governments should be able to select top-level management on SOEs who shall then have autonomy. After that, the selection of personnel (both at top and middle levels) should only be made from specific lists detailing candidates with certified expertise based on free-access comparative selection procedures. To do this, advanced and 
professional schools for public management should be enforced, creating incentive schemes to encourage young people who are motivated and prepared for a public career. Future work will concentrate on an international comparison of controlled companies and SOEs' governance, regulation and performance in specific sectors by share of ownership.

\section{References}

Afonso, Antonio, Ludger Schuknecht and Vito Tanzi (2005) 'Public sector efficiency: an international comparison', Public choice 123(3-4):321-347.

AGCOM (2014) Audizione presso la IX Commissione della Camera dei Deputati del Presidente dell'Autorità garante della concorrenza e del mercato Professor Giovanni Pitruzzella. Indagine conoscitiva sul settore del trasporto pubblico locale.

Allum, Percy A. (1974) ?Italy—Republic without Government?The World Today' 30(11): 448-459.

Al-Obaidan, Abdullah M. and Gerald W. Scully (1992) 'Efficiency differences between private and state-owned enterprises in the international petroleum industry', Applied Economics 24(2): 237-246.

Amaral, Miguel (2008) 'Public vs private management of public utilities-The case of urban public transport in Europe', Research in transportation Economics 22(1): 8590.

Amaral, Miguel, Stéphane Saussier and Anne Yvrande-Billon (2009) 'Auction procedures and competition in public services: The case of urban public transport in France and London', Utilities Policy 17(2):166-175.

Andrews, Rhys, George A. Boyne and Gareth Enticott (2006) 'Performance failure in the public sector: misfortune or mismanagement?', Public Management Review 8(2): 273-296.

Arnold, Jens M., Giuseppe Nicoletti and Stefano Scarpetta (2011) 'Regulation, resource reallocation and productivity growth', European Investment Bank Papers 16(1): 90-115.

Arrigo, Ugo and Giacomo Di Foggia (2013) 'Schemes and Levels of State aid to Rail Indutry in Europe: Evidences From a Cross-Country Comparison', European Journal of Business and Economics 8(3):14-20.

Arrow, Kenneth J. (1974) The Limits of Organization. Fels Lectures on Public Policy Analysis. London: Ww Norton \& Co.

Asquer, Alberto (2011) 'Liberalization and regulatory reform of network industries: A comparative analysis of Italian public utilities', Utilities Policy 19(3):172-184.

Bandiera, Oriana, Andrea Prat and Tomasso M. Valletti (2008) Active and Passive Waste in Government Spending: Evidence from a Policy Experiment. CEIS Working Paper (115). Retrieved from: http://ssrn.com/abstract=1115339.

Bator, Francis M. (1958) 'The anatomy of market failure. The Quarterly Journal of Economics' 72(3): 351-379.

Boitani, Andrea, Marcelo Nicolini and Carlo Scarpa (2009) Do Competition and Ownership Matter? Evidence from Local Public Transport in Europe. Working Papers SIET 2009 - ISSN 1973-3208.

Bottasso, Anna and Alessandro Sembenelli (2004) 'Does ownership affect firms' efficiency? Panel data evidence on Italy', Empirical Economics 29(4):769-786.

Boubakri, Narjess, Jean Claude Cosset and Walid Saffar (2008) 'Political connections of newly privatized firms' Journal of Corporate Finance 14(5): 654-673. 
Bovaird, Tony and Elke Löffler (2009) Public management and governance. Taylor \& Francis: Abingdon.

Boycko, Maxim, Andrei Schleifer and Robert W. Vishny (1996) 'A theory of privatisation', Economic Journal 106(435): 309-319.

Brennan, Willian J. Jr.(1977) 'State constitutions and the protection of individual rights', Harvard Law Review 90(3):489-504.

Brown, Trevor L., Mattew Potoski and David M. Van Slyke (2006) 'Managing public service contracts: Aligning values, institutions, and markets', Public Administration Review, 66(3):323-331.

Buchanan, James M. (1968) The demand and supply of public products (Vol. 6). Chicago: Rand McNally.

Caciagli, Mario (2006) 'The long life of Clientelism in southern Italy', in Kawata, J. (ed.) Comparing Political Corruption and Clientelism, 157-170, Burlington: Ashgate.

Calandra, Piero (1978) Storia dell'amministrazione pubblica in Italia [history of Italian Public Administration] (Vol. 180), Bologna: II Mulino.

Capano, Giliberto (2003) 'Administrative traditions and policy change: when policy paradigms matter. The case of Italian administrative reform during the 1990s', Public Administration, 81(4):781-801.

Cassese, Sabino (1993) 'Hypotheses on the Italian administrative system', West European Politics, 16(3): 316-328.

Dabla-Norris, Era, Jim Brumby, Annette Kyobe, Zac Mills and Chris Papageorgiou (2012) 'Investing in public investment: an index of public investment efficiency', Journal of Economic Growth, 17(3): 235-266.

Dahl, Robert A. (1947) 'The science of public administration: Three problems', Public Administration Review, 7(1): 1-11.

Del Monte, Alfredo and Erasmo Papagni (2001) 'Public expenditure, corruption, and economic growth: the case of Italy', European Journal of Political Economy, 17(1): 1-16.

Della Porta, Donatella and Alberto Vannucci (1997) 'The 'perverse effects' of political corruption', Political studies 45(3): 516-538.

Dewenter, Kathryn L.and Paul H. Malatesta (2001) 'State-owned and privately owned firms: An empirical analysis of profitability, leverage, and labor intensity', The American Economic Review, 91(1): 320-334.

Dwyer, Larry and Deborah Edwards (2009) 'Tourism Product and Service Innovation to Avoid "Strategic Drift" 1, International Journal of Tourism Research, 11(4): 321-335.

Entwistle, Tom and Steve Martin (2005) 'From competition to collaboration in public service delivery: a new agenda for research', Public administration 83(1): 233-242.

Esping-Andersen, Gosta (1990) The three worlds of welfare capitalism (Vol. 6). Cambridge: Polity press.

European Commission (2014a) Directorate-General for Competition, Competition Policy in the European Union. Retrieved from http://ec.europa.eu/dgs/competition/index_en.htm.

European Commission (2014b. Report on Competition Policy 2013 \{SWD(2014) 148 final\}.

Fiorino, Nadia, Emma Galli and Ilaria Petrarca (2012) 'Corruption and Growth: Evidence from the Italian regions', European Journal of Government and Economics 1(2): 126-144. 
Forrer, John, James E. Kee, Kathryn E. Newcomer and Eric Boyer (2010) 'Publicprivate partnerships and the public accountability question', Public Administration Review, 70(3): 475-484.

Frank, Robert H., Ben Bernanke and Louis D. Johnston (2007) Principles of economics. New York: McGraw-Hill//rwin.

Fratianni, Michele and Franco Spinelli (1982) 'The growth of Government in Italy: Evidence from 1861 to 1979', Public Choice 39(2): 221-243.

Frederickson, H. George, Kevin B. Smith and Christopher W. Larimer (2003) The public administration theory primer. Boulder, CO: Westview Press.

García, César (2013) 'Clientelism, Economic Structure, and Public Relations in Southern Europe: An Example of Diversity in the Western World',. Public Relations Journal 7(2): 214-241.

Garrone, Paola, Luca Grilli and Xavier Rousseau (2013) 'Management discretion and political interference in municipal enterprises. Evidence from Italian utilities', Local Government Studies 39(4): 514540.

Guardia di Finanza (2014) Rapporto annuale 2013 [Annual report 2013].

Grandy, Christopher (2009) 'The "Efficient" Public Administrator: Pareto and a Well-Rounded Approach to Public Administration', Public Administration Review, 69(6):1115-1123.

Guzzini, Stefano (1995) 'The 'long night of the first republic': Years of clientelistic implosion in Italy', Review of International Political Economy 2(1): 27-61.

Habermas, Jürgen (1994) 'Three normative models of democracy', Constellations 1(1): 1-10.

Haque, M. Shamsul (2001) 'The diminishing publicness of public service under the current mode of governance', Public Administration Review, 61(1): 65-82.

Hartley, Jean, Eva Sørensen and Jacob Torfing (2013) 'Collaborative Innovation: A Viable Alternative to Market Competition and Organizational Entrepreneurship', Public Administration Review 73(6): 821-830.

Haskel, Jonathan and Stefan Szymanski (1992) 'A bargaining theory of privatization', Annals of Public and Cooperative Economics, 63(2): 207-228.

Heady, Ferrel (2001) Public administration, a comparative perspective. New York: CRC Press.

Hood, Christopher (2000) 'Paradoxes of public-sector managerialism, old public management and public service bargains', International Public Management Journal 3(1): 1-22.

Istituto Bruno Leoni (2012) Indice delle liberalizzazioni 2012 [Index of Liberalisation 2012]. Torino: IBL Libri.

Jonsson, Ernst (1984) 'Recurrent cost and performance comparisons within public administration: A method of generating efficiency-promoting competition' Public Choice 42(2): 185-192.

Kettl, Donald F. (2002). The transformation of governance: Public administration for twenty-first century America. Baltimore: Johns Hopkins University Press.

Kowalski, Przemyslaw, Max Büge, Monica Sztajerowska and Matias Egeland (2013) State-Owned Enterprises: Trade Effects and Policy Implications, OECD Trade Policy Paper, No. 147, OECD Publishing. 
Martimort, David and Jerome Pouyet (2008) 'To build or not to build: Normative and positive theories of public-private partnerships', International Journal of Industrial Organization 26(2):393-411.

Ministero dell'Economia e delle Finanze (2013) Rapporto sulle partecipazioni detenute dalle Amministrazioni Pubbliche al 31 dicembre 2011 [Report of Participation of public administrations by December 31 2011]

Musgrave, Richard A. (1959) The Theory of Multi-Level Public Finance. In Proceedings of the Annual Conference on Taxation under the Auspices of the National Tax Association (pp. 266-278). National Tax Association.

Newman, Meredith A. (1994) 'Gender and Lowi's thesis: Implications for career advancement', Public Administration Review, 54 (3): 277-284.

Niskanen, Willian A. (1973) Bureaucracy: Servant or master? London: The Institute of Economic Affairs.

Nozick, Robert (1974). Anarchy, state and utopia. New York: Basic books.

Organisation for Economic Co-operation and Development (2004) Access pricing in telecommunication. Paris: OECD Publishing.

Organisation for Economic Co-operation and Development (2006) Comparative Report on Corporate Governance of State-owven Enterprise. Paris: OECD Publishing

Ongaro, Edoardo (2008) 'Introduction: the reform of public management in France, Greece, Italy, Portugal and Spain', International Journal of Public Sector Management 21(2): 101-117.

Ongaro, Edoardo and Giovanni Valotti (2008) 'Public management reform in Italy: explaining the implementation gap', International Journal of Public Sector Management 21(2): 174-204.

Osborne, Stephen P. and Kirsty Strokosch (2013) 'It takes Two to Tango? Understanding the Co-production of Public Services by Integrating the Services Management and Public Administration Perspectives', British Journal of Management, 24(S1): S31-S47.

Ostrom, Vincent and Elinor Ostrom (1971) Public choice: A different approach to the study of public administration. Public Administration Review 31(2): 203-216.

Peters, B. Guy and John Pierre (1998) 'Governance without Government? Rethinking public administration', Journal of public administration research and theory 8(2): 223-243.

Piattoni, Simona (Ed.) (2001) Clientelism, interests, and democratic representation: the European experience in historical and comparative perspective. New York: Cambridge University Press.

Pitlik, Hans, Werner Hölzl, Christof Brandtner, Friedrich Heinemann, Florian Misch, Mustafa Yeter, Geert Steurs, Simon Gagnage and Kristof Mertens (2012) Excellence in public administration for competitiveness in EU Member States. Report for the European Commission, DG Enterprise and Industry.

Pizam, Abraham (Ed.) (2010) International Encyclopedia of Hospitality management (Second Ed.). Oxford: Elsevier.

Pollitt, Christopher. A. (2004) Public management reform: A comparative analysis. New York: Oxford University Press.

Putnam, Robert D., Robert Leonardi and Raffaella Y. Nanetti (1994) Making democracy work: Civic traditions in modern Italy. Princenton: Princeton University Press. 
Raadschelders, Jos C.N. and Kwang-HoonLee (2011) 'Trends in the Study of Public Administration: Empirical and Qualitative Observations from Public Administration Review, 2000-2009', Public Administration Review 71(1):19-33.

Rainey, Hal G., Robert W. Backoff, and Charles H. Levine (1976) 'Comparing public and private organizations', Public Administration Review, 36(2):233-244.

Sapienza, Paola (2004) 'The effects of Government ownership on bank lending', Journal of Financial Economics 72(2): 357-384.

Schmidt, V. A. (2006) 'Procedural democracy in the EU: the Europeanization of national and sectoral policy-making processes', Journal of European Public Policy 13(5): 670-691.

Shleifer, Andrei and Robert W. Vishny (1994) 'Politicians and firms', The Quarterly Journal of Economics, 109(4): 995-1025.

Spicer, Michael W. (2010) In defense of politics in public administration: A value pluralist perspective.Tuscaloosa: University of Alabama Press.

Tanzi, Vito (1998) Corruption around the world: Causes, consequences, scope, and cures. International Monetary Fund Working Paper WP/98/63.

Toninelli, Pier A. (Ed.) (2000) The rise and fall of state-owned enterprise in the Western world (Vol. 1). New York: Cambridge University Press.

Torres, Lourdes (2004) 'Trajectories in public administration reforms in European Continental countries', Australian Journal of Public Administration, 63(3): 99-112.

Walsh, Ciaran (2003) Key management ratios. Master the management metrics that drive and control your business (3rd ed.). Harlow: Financial Times Prentice Hall Publishing.

Warner, Mildred E. (2011) 'Competition or cooperation in urban service delivery?', Annals of Public and Cooperative Economics 82(4): 421-435.

Willner, Johan (2001) 'Ownership, efficiency, and political interference', European Journal of Political Economy,17(4): 723-748.

Zheng, Jinghai, Xiaoxuan Liu and Arnbe Bigsten (2003) 'Efficiency, technical progress, and best practice in Chinese state enterprises (1980-1994)', Journal of Comparative Economics 31(1):134-152. 